\title{
Sport, iszkémiás szívbetegséggel
}

\author{
Szelid Zsolt \\ Testnevelési Egyetem, Sportkardiológiai Szakambulancia, Budapest \\ Semmelweis Egyetem, Városmajori Szív- és Érgyógyászati Klinika, Budapest \\ Levelezési cím: \\ Dr. Szelid Zsolt PhD, med. habil., E-mail: szelidzs@gmail.com
}

Az iszkémiás szívbetegség fokozott hirtelen szívhalál kockázatot jelenthet, amit az intenzív sportaktivitás fokozhat. Szívizom-iszkémia mellett, valamint szívinfarktust követően az intenzív sporthoz való visszatérés lehetséges, azonban a terhelhetőség orvosi megítélése során számos tényezőt kell figyelembe venni. Iszkémiás szívbetegség gyanúja esetén elsősorban a betegségrizikó mérlegelése, igazolt koszorúsér-betegség esetén pedig az akut koronáriaesemény rizikójának megítélése az elsődleges feladat. A versenysporttal kapcsolatos rizikómeghatározások lényeges eleme a teljes kifáradásig történő terheléses tesztek elvégzése, valamint koronária-CT-angiográfia-vizsgálat elvégzése, ami a betegek számára a biztonságos „return-to-sport” lehetőségét jelentheti.

Kulcsszavak: iszkémiás szívbetegség, sport, versenysport

\section{Sport activity with ischaemic heart disease}

Ischaemic heart disease may result in enhanced risk for sudden cardiac death, which can be triggered by intensive sport activity. In ischaemic heart disease, and in post-infarct patients, return to sport is possible, but several sport-related aspects are needed to be considered before the correct medical decision. In patients with suspected coronary artery disease, risk stratification has to be performed, while in patients with confirmed coronary artery disease the prediction of the acute event risk is needed. Important diagnostic modalities in this examination protocol include exercise tests to exhaustion and coronary CT angiography.

Keywords: ischaemic heart disease, sport, competitive sport

A heveny szívbetegségeket követő fizikai terhelés megítélésére a kezelőorvosok hosszú ideig azt tanácsolták a betegeknek, hogy „csak óvatosan”. Ma már léteznek olyan ajánlások, amelyek a sportoláshoz való visszatérés szabályait tartalmazzák. Ezek egyrészt figyelembe veszik az adott sportág jellegét, valamint megítélik az adott beteg rizikóját a hirtelen szívhalálra, vagy a betegség progressziójára vonatkoztatva. Ezek az ajánlások elsősorban az intenzív edzésmunkát végző betegek elbírálására születtek, de valójában jól alkalmazhatóak az amatőr sportot üző, rendszeres fizikai tréninget igénylő páciensek terhelhetőségére is.

\section{Külo̊nbo̊ző sportágak kardiális hatásai}

A rendszeres sporttevékenységnek különböző sportágak esetén különböző szív- és érrendszeri hatásai alakulnak ki (1). A sportokat a sportági dinamikus és statikus komponensek alapján oszthatjuk fel (1. ábra), ami alapján négy fő csoportra oszthatjuk a sportágakat:

- technikai,

- állóképességi,

- erő,

- valamint kevert típusú sportok (1. ábra).

A technikai típusú sportok elsősorban magas szintü ideg-izom koordinációt igényelnek, fizikai terhelésük

A kézirat 2020. 09. 01-jén érkezett a szerkesztőségbe, 2020. 10. 28-án került elfogadásra. 


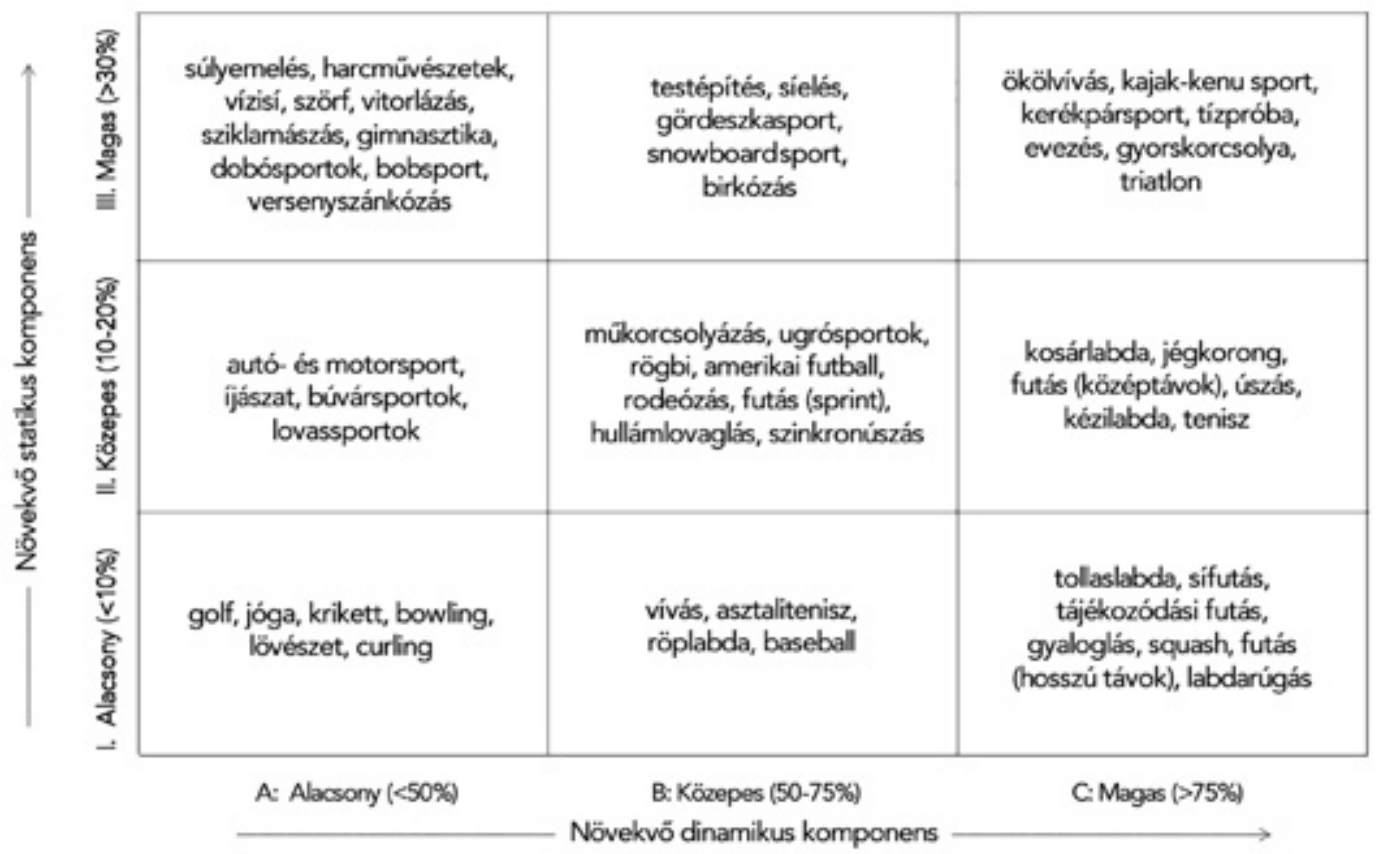

1. ÁBRA. Sportágak klasszifikációja. A sportágak a dinamikus és statikus komponens mértéke alapján kilenc kategóriába oszthatók. A különböző intenzitású dinamikus komponens a maximális oxigénfelvétel százalékos mértékét, a statikus komponens pedig a maximális izomerő százalékos arányát jelenti az adott sportágakban (Forrás: Levine, JACC, 2015)

viszont alacsony statikus és alacsony dinamikus terhelést jelentenek (I.A típusú sportok) (1. ábra). Amint a 2. ábra mutatja, ezek a sportok alacsony-közepes mértékben emelik meg a pulzusszámot és csak kis mértékben emelik a szisztolés vérnyomást, valamint a perctérfogatot. A technikai sportok rendszeres gyakorlása mellett csekély mértékú kardiális sportadaptáció alakul ki. $\mathrm{Az}$ erősportok elsősorban a leginkább igénybe vett izomcsoportok statikus terhelését jelentik és így azok hipertrófiáját alakítják ki. A típusos erősportokban (1. ábra, III.A sportok) az állóképességi dinamikus terhelés alacsony, a statikus terhelés azonban jelentős mértékü, ami akut hatása során nagymértékben emeli a szisztolés vérnyomást (gyakori, de rövid időtartamokban) és közepes mértékben növeli a pulzust, valamint a perctérfogatot (2. ábra). A típusos erősportok hosszútávon jelentős mértékü szívizom-hipertrófiát és mérsékelt balkamra-dilatációt okoznak.

A főként dinamikus, kardiójellegű edzésmunkát igénylő állóképességi sportok (I.C sportok, pl. a labdarú-

Technikai sportágak
\begin{tabular}{|l|l|}
\hline Pulzus & $+/++$ \\
\hline Vérnyomás & + \\
\hline Perctérfogat & + \\
\hline Sportsziv & - \\
\hline
\end{tabular}

Golf
Vitorlázás
Autó/ Motorsport
Asztalitenisz
Lovaglás
Lơvészet
fjászat
Karate
Curling
Szánkózás
Siugrás

\begin{tabular}{|l|l|}
\multicolumn{2}{c}{ Erôsportágak } \\
\hline Pulzus & ++ \\
\hline Vérnyomás & +++ \\
\hline Perctérfogat & ++ \\
\hline Sportsziv & + \\
\hline
\end{tabular}

Súlyemelés

Birkózás/Dzsúdó

Ökölvivás

Rövidtávfutás

Súlylökés

Diszkoszvetés

Szertorna

Bob

Rövidpályás gyorskorcsolya

Alpesisí

Snowboard
"Kevert" sportágak

\begin{tabular}{|l|l|}
\hline Pulzus & $++/+++$ \\
\hline Vérnyomás & ++ \\
\hline Perctérfogat & $++/+++$ \\
\hline Sportszív & ++ \\
\hline
\end{tabular}

Labdarúgás

Kosárlabda

Röplabda

Vizillabda

Tollaslabda

Tenisz

Vivás

Kézilabda

Rugby

Hoki/jégkorong

Állóképességi sportágak
\begin{tabular}{|l|l|}
\hline Pulzus & +++ \\
\hline Vérnyomás & ++ \\
\hline Perctérfogat & +++ \\
\hline Sportszív & +++ \\
\hline
\end{tabular}

Kerékpársport

Közép- hosszútávúszás

Közép- hosszútávfutás

Kenusport

Triatlon

Öttusa

Sifutás

Biation

Gyorskorcsolya

(kivétel: rövidtáv)

2. ÁBRA. Sportágak akut szív- és érrendszeri hatásai. Az akut fizikai terhelés alapján megkülönböztetünk alacsony intenzitású, főként technikai sportágakat, döntően statikus erőkifejtéssel járó erősportágakat, valamint állóképességi sportágakat. Az akut erő- és állóképességi terhelést egyaránt igénylő sportágak a kevert típusúak 
gás) a terhelés során emelkedett perctérfogattal és magas pulzusszámmal, valamint közepes mértékben emelkedett vérnyomással járnak (2). Krónikus kardiális hatások extrém mértékben versenysportolók esetében alakulnak ki, akik napi több órás edzésmunkát végeznek. Magas intenzitású, rendszeres állóképességi terhelés mellett közepes fokú balkamra-hipertrófia és jelentős balkamra-dilatáció alakulhat ki. Ennek mértékét azonban több tényező is befolyásolhatja, így a sportoló neme, kora, etnikuma, testméretei, testösszetétele, táplálkozása, valamint csapat- sportok esetében a sportági posztja (lásd: csatár és kapus) is.

Kevert típusú sportokról akkor beszélünk, ha az adott sportág együttesen tartalmaz, dinamikus, statikus terhelési és technikai elemeket. Ide tartozik a labdajátékok és a csapatsportok nagy része. Ezekben a sportokban a sportolók versenyszintű terhelési időtartama és intenzitása nagyon különbözik. Hiszen míg egyéni sportokban az adott versenyzőnek teljesíteni kell a versenycélt, addig csapatsportok esetén a játékosok lecserélhetőek. A kevert típusú sportokban az akut terhelés során köze-
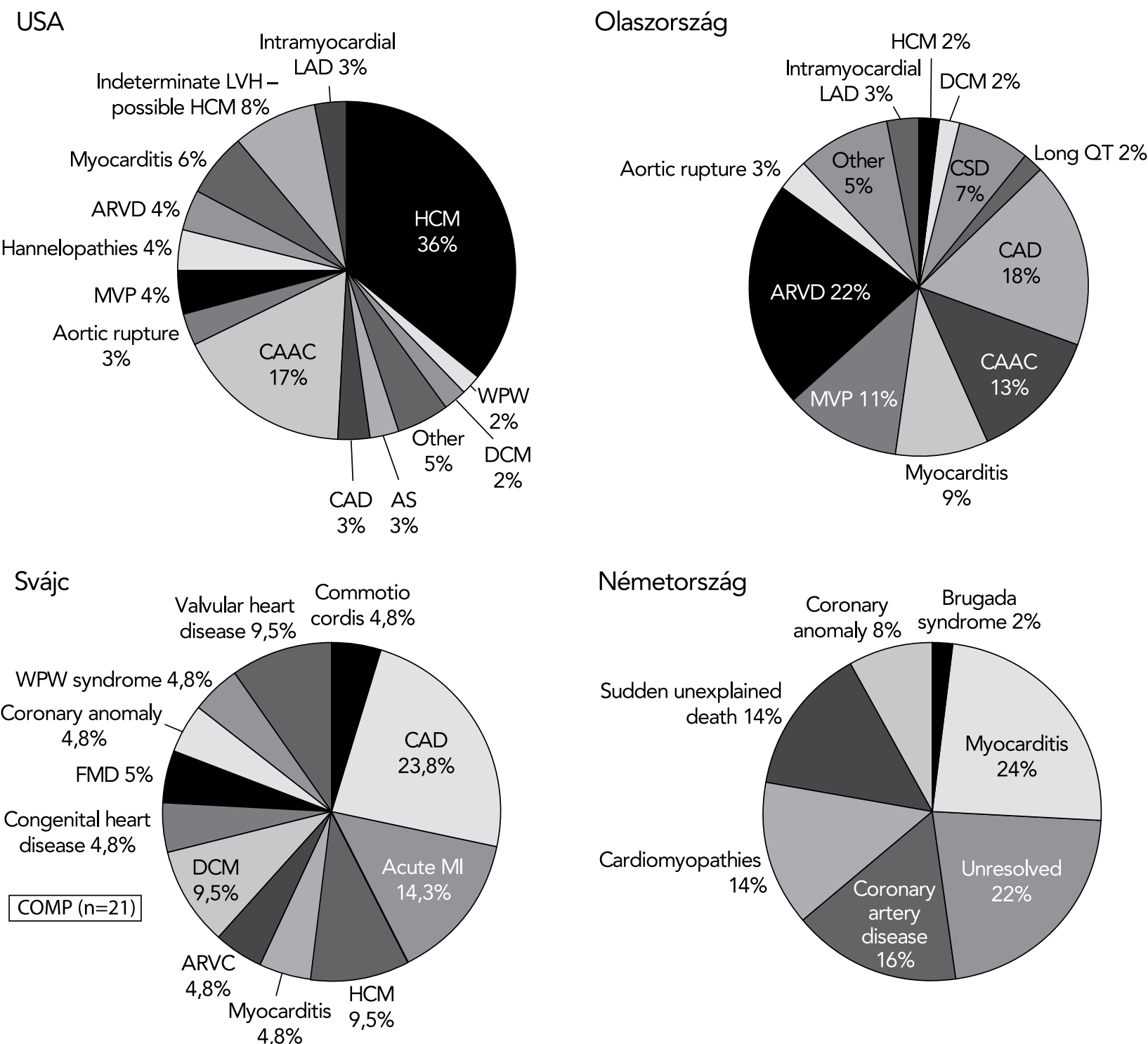

Szívizombetegségek: HCM, DCM, ARVD, Cardiomyopathies, Ingerképzési és vezetési zavarok: Channelopathies, Brugada sy, WPW, severe AV blocks, RBBB, LBBB Szívizomgyulladás: Myocarditis

Koronáriabetegség: CAD (Coronary artery disease), CAAC (Coronary anomaly), Acute MI (myocardial infarction)

3. ÁBRA. Hirtelen szívhalál etiológiája fiatal sportolókban a nemzeti regiszterek alapján. Négy ország regisztereinek adatai kördiagramokon. A diagramokon feltüntetett gyakoribb kórképek négy csoportba sorolhatók: szívizombetegségek, ingerképzési és vezetési zavarok, szívizomgyulladás és koronáriabetegség 
pes mértékben emelkedik a vérnyomás, a pulzus és a perctérfogat pedig az adott sportágtól függően közepes, vagy jelentős mértékben nő meg. Mindezek hatására a sportági kardiális adaptációs jelek dinamikus és statikus terhelésre jellemző elemeket is magukba foglalnak.

\section{Sportorvosi vizsgálat: primer prevenció}

Versenysport-engedéllyel rendelkezők esetében rendszeres sportorvosi vizsgálat történik, amelynek célja az egészség megőrzése, a hirtelen szívhalál megelőzése és a sérülések kivédése. A vizsgálat valódi primer prevenciós eszköz, hiszen szürővizsgálati jelleggel, panaszmentes személyeken történik. Idősebb (>65 éves kor) sportolókon a vizsgálati eredmény fél évig érvényes, mivel ebben a populációban a társbetegségek és a koronáriabetegség miatt az amatőrszintű sportaktivitás is fokozhatja a hirtelen szívhalálrizikót (2). A fizikai terhelés akut kardiovaszkuláris hatásai miatt (2. ábra), a sport, meglévő betegségek esetén fokozhatja a hirtelen szívhalál kockázatát. Nemzetközi regiszteradatok alapján a versenysportolók hirtelen halálának incidenciája 1-3/100 000 sportoló/év (3). A hirtelen szívhalál hátterében elsősorban rejtett szívbetegség áll (3. ábra). A nemzeti regiszterek azt mutatják, hogy a sportoló fiatalok fatális eseményeit elsősorban szívizombetegség, ingerképzési, vagy ingervezetési zavar, vagy szívizomgyulladás okozzák. A klasszikus koronáriabetegség, vagy szívinfarktus elsősorban a 35 éves kor feletti sportolók esetén jelent komoly veszélyt. El kell mondani, hogy a regiszterek közül ennek viszont a német (4) és a kisebb létszámú svájci regiszter mond némiképp ellent, ahol a fiatal sportolók esetén is komoly hányadban észleltek szívinfarktust és koronáriabetegséget. Ennek oka nem egyértelmü, de a 3. ábrán feltüntetett regiszterek között ezek a legkisebb létszámú populációk, ami befolyásolja az eredményüket, valamint a svájci adatokban negyvenéves kor alattiakat tekintettek fiatal sportolónak.

A sportorvosi vizsgálat során a vizsgálat része a kórelőzmény kikérdezése mellett a fizikális vizsgálat, a 12 elvezetéses EKG és a brachialis vérnyomásmérés is. A nyugalmi vérnyomás normál maximális értéke 18 éves kor alattiak esetében a kor-, a nem- és a testmagassághoz igazított percentilis értékek alapján kerül megállapításra. A nyugalmi EKG sportolók esetében normál, sporttal összefüggő eltérést is mutathat. A jelenlegi nemzetközi konszenzusos irányelv (5) alapján a normál sporttal összefüggő EKG-variánsok közé a következők tartoznak: bal- és jobbkamra-hipertrófia QRS-kritériumok jelenléte, inkomplett jobb Tawaraszár-blokk, korai repolarizációs jelek (ST-szegmenteleváció), sinus bradycardia ( $\geq 30 / \mathrm{min})$, sinusaritmia, ectopiás pitvari-, vagy junkcionális ritmusok, első fokú-, vagy Mobitz I. típusú másodfokú AV-blokkok. Normál sportolói variancia 16 éves kor alattiak esetében a $V_{1-3}$ elvezetésekben látható T-hullám-negativitás, valamint fekete sportolók esetében a $V_{1-4}$-elvezetésekben látható negatív T-hullám. A fiatalokhoz képest a 35 éves kor felettiek esetében az iszkémiás szívbetegséggel összefüggő hirtelen szívhalál kockázata jelentősen megnő. Ezért lényeges az, hogy az elmúlt években egyre több adat jelent meg az iszkémiás szívbetegség melletti sportaktivitás megítélésével kapcsolatban, ami mára irányelvvé érett.

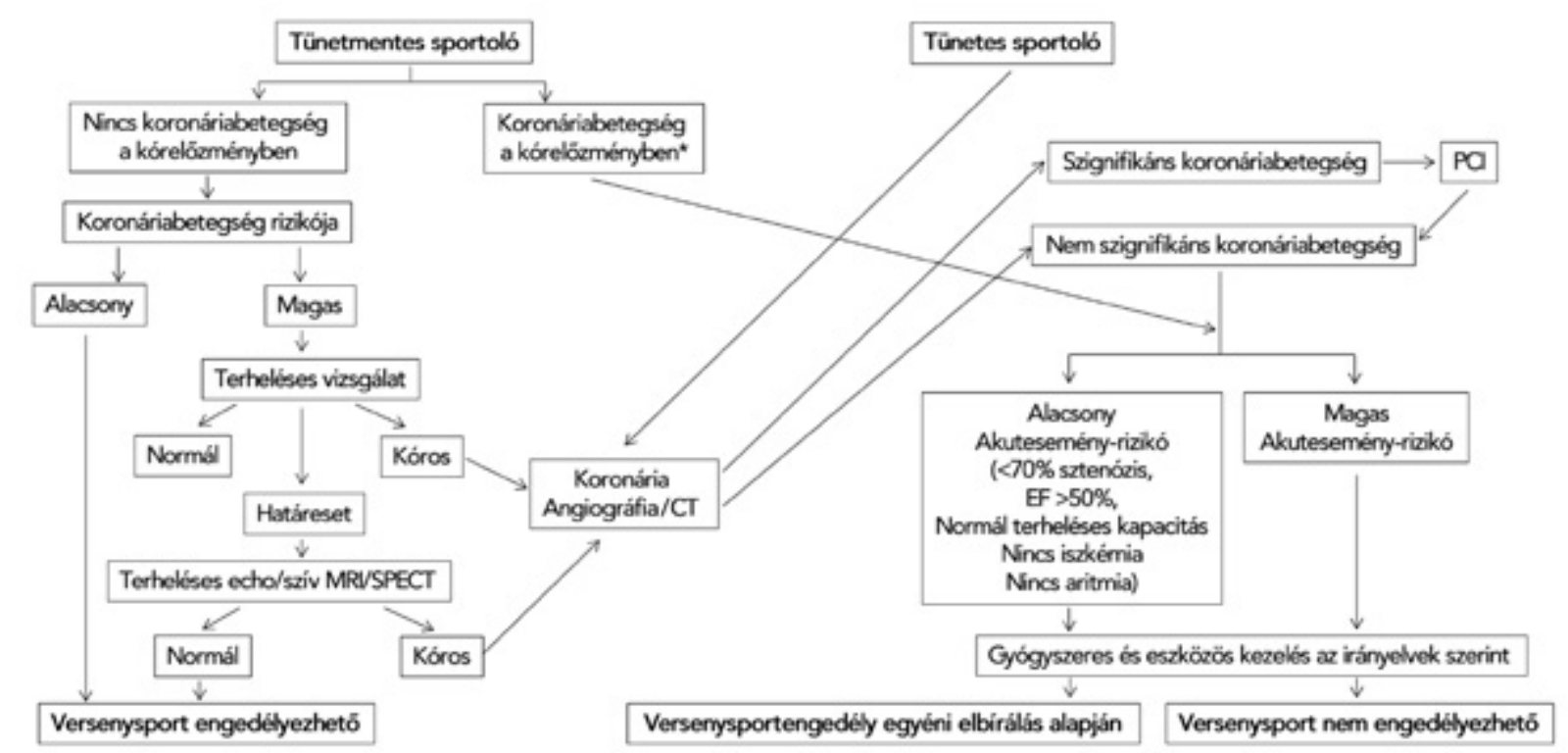

- EløaCleg dokumentált Klinikai esemény, pozitiv koronária-CT, vagy pozitiv koronáriaangiográfia

4. ÁBRA. Biztonságos versenysport megítélése a koronáriabetegség rizikója és súlyossága alapján. Sportolók javasolt kivizsgálási algoritmusa a versenysportengedély kiadását megelőzően (Forrás: Borjesson et al, EHJ 2019) 


\section{Iszkémiás szívbetegség és a sport}

Amennyiben tünetmentes sportolókban az elvégzett szürővizsgálatok alapján koronáriabetegség gyanúja merül fel, terheléses EKG-teszt elvégzése szükséges gázcserés méréssel vagy anélkül $(6,7)$ (4. ábra). Ha a terheléses vizsgálat során nem provokálható iszkémia (teljesen negatív), akkor annak évente történő ismétlésével engedhető az élsport. Fontos megjegyezni, hogy versenysport esetén maximális kapacitással elvégzett terheléses teszt elvégzése javasolt, ami a sportoló teljes kifáradásáig tart. Ekkor van lehetőség az esetleges anaerob körülmények között megjelenő ritmuszavarok, vagy iszkémiás eltérések vizsgálatára (7). Amennyiben a terheléses EKG határérték-pozitivitást mutat $(0,5 \mathrm{~mm}$ STD, vagy nem típusos ascendáló ST-eleváció), vagy a nyugalmi bal Tawara-szár-blokk miatt eleve értékelhetetlen a terheléses EKG, akkor a következő lépés a terheléses képalkotó vizsgálat (terheléses echo/cMR/ PET/SPECT). Ha a terheléses EKG pozitív eltérést mutat, akkor koronária-CT, vagy invazív koronária-angiográfia a következő diagnosztikus lépés. Amennyiben a szürővizsgálat során nem igazolódik koronáriabetegség, vagy annak gyanúja, akkor a versenysportengedély kardiális szempontból megadható (4. ábra). Amenynyiben nem szignifikáns koronáriabetegség igazolódik, akkor az úgynevezett „koronáriaesemény-rizikó” meghatározása szükséges (4. ábra). Alacsony „koronáriaesemény-rizikó" mellett a versenysportengedély megadása egyénileg mérlegelhető. Ez vonatkozik arra a sportolóra is, akinél perkután koronáriaintervenciót követően sikeres és teljes revaszkularizációja történt. Az ilyen eseteket ugyancsak nem-szignifikáns koronáriabetegségként kell értékelni. Magas akut eseményrizikó jelenléte esetén azonban a versenysport nem engedélyezhető (4. ábra). Panaszos sportoló esetén az első lépés a pontos diagnózishoz jutás, amit koronária-CT, vagy invazív koronarográfia elvégzésével tudunk meg. Az így kapott diagnózis és versenysport megítélés az elöbbi algoritmushoz hasonlít, vagyis ha nem-szignifikáns koronáriabetegség igazolódik, vagy a beteg sikeres perkután koronáriaintervención van túl, akkor kardiális szempontból a sportengedély megadása az egyén koronáriaesemény-rizikó meghatározását követően ítélhető meg és döntés elött javasolt az abban jártas szakember bevonása (4. ábra).

Az Európai Kardiológusok Társaságának ajánlása az iszkémiás szívbetegséggel rendelkező sportolók diagnosztikájára és terhelésére (6):

1. Amennyiben a maximális terheléses EKG-teszt normális és a kardiovaszkuláris rizikó alacsony, akkor a koronáriabetegség valószínűsége kicsi, a versenysport korlátozás nélkül engedélyezhető valamennyi sportágban (ESC-ajánlás: II.a, C-szintű evidencia) (7). Amennyiben a terheléses EKG-teszt eredménye normális, de fennáll kardiovaszkuláris rizikó, akkor versenysport esetén évente javasolt a rizikó- faktorok kontrollja és terheléses EKG-teszt elvégzése.

2. Amennyiben a terheléses EKG-teszt határérték eltérést mutat, akkor terheléses képalkotó vizsgálat elvégzése szükséges (echo, SPECT, PET, cMR). Ennek során a maximális terhelhetőség elérése a cél, lehetőség szerint fizikális és nem gyógyszeres terheléssel. Amennyiben ennek feltételei nincsenek meg, akkor gyógyszeres módon is végrehajtható a terhelés. Amennyiben a terheléses képalkotó teszt normáleredményt mutat, akkor a versenysport engedélyezhető, de évente javasolt terheléses EKG kontrollvizsgálat és rizikófaktorok kontrollja.

3. Amennyiben a terheléses EKG, vagy a terheléses képalkotó teszt eredménye pozitív, akkor koronária-CT-vizsgálat, vagy invazív koronarográfia-vizsgálat elvégzése szükséges. Szeniorsportolók esetében, szignifikáns stenosis hiánya mellett is, a koronária kalciummennyisége normálesetben magasabb, mint a nem sportoló, hasonló korú egyéneké. Mindezek miatt a koronária-CT megítélése elsősorban sportolókban jártas képalkotó szakember bevonását teszi szükségessé.

4. Igazolt koronáriabetegség esetén, amennyiben a koronáriaesemény kockázata alacsony, akkor a versenysportengedély egyéni mérlegelése szükséges és lehetséges. Az akut kardiovaszkuláris és esetleges elektrolitzavart okozó hatásai miatt azonban az extrém erő, vagy állóképességi terheléssel járó sportok (2. ábra) esetén a versenyengedély csak fokozott körültekintéssel adható meg és lehetöség szerint jártas szakemberekből álló teamdöntés javasolt. Itt feltétlenül szükséges figyelembe venni, hogy 60 éves kor felett az extrém állóképességi terhelés fokozott hirtelen szívhalálkockázattal járhat (ajánlás: II.a, C-szintü evidencia).

5. Igazolt koronáriabetegség esetén, amennyiben a „koronáriaesemény-kockázat” magas, ekkor a versenysportengedély nem adható meg. Amennyiben a „koronáriaesemény-kockázat” a későbbiekben alacsonnyá válik (pl. ismételt revaszkularizáció), akkor a versenyengedély egyénileg mérlegelhető lehet (ajánlás: II.a, C-szintű evidencia).

A koronáriabetegséggel rendelkező sportolók kezelése során az egyéb klinikai irányelvek (pl. gyógyszeres kezelés, eszközös kezelések) természetesen ugyanúgy érvényesek, mint nem sportolók esetében. Kiemelendő az antitrombotikus kezelés megítélése, ami fokozhatja a vérzésveszélyt, ezért kettős antitrombocita-kezelés alatt álló sportolók esetén a kontaktsportágakban való részvétel nem javasolt (7).

Szívizom-iszkémia hátterében nem csak klasszikus koronáriabetegség állhat. További tényezők lehetnek: kongenitális koronáriaartéria-anomáliák, koronáriaartéria-disszekció, valamint a myocardium-bridge.

Az Európai Kardiológusok Társaságának ajánlása nem ateroszklerotikus koronáriabetegség miatt kialaku- 
ló myocardium-iszkémiás szívbetegségben szenvedő sportolók diagnosztikájára és terhelésére (6):

1. A kongenitális anomáliák közül a következők okoznak fokozott hirtelenszívhalál-kockázatot: bal anterior descendens koronáriaartéria (LAD) a jobb sinus Valsalvából, vagy a jobb koronáriaartéria (RCA) a bal sinus Valsalvából ered, az ér éles kanyarral ered az aortából és lefutásakor az aorta és a pulmonalis artéria között halad át. Ekkor, különösen panaszos, vagy tünetes esetekben a sebészi korrekció abszolút szóba jön és azt megelőzően a versenysport nem engedélyezhető (ajánlás: II., C-szintű evidencia).

2. Amennyiben az eredési anomáliával rendelkező ér nem halad át az aorta és a pulmonalis artéria között, akkor a hirtelen szívhalál kockázata alacsonynak minősül. Ekkor iszkémia provokációs terheléses teszt elvégzése szükséges és annak negativitása esetén sebészi korrekció nem indokolt, a versenysportengedély pedig egyénileg mérlegelhető (ajánlás: III., C-szintü evidencia).

3. A koronáriaanomália korábbi sebészi korrekcióját követően, amennyiben nem provokálható a myocardium-iszkémia, akkor minden versenysport engedélyezhető (ajánlás: III., C-szintü evidencia).

4. Más típusú kongenitális koronáriaartéria-anomália esetén (ide tartozik a circumflex artéria jobb sinus Valsalvából való eredési anomáliája), amennyiben terheléses teszt során nem provokálható iszkémia, akkor a versenysport engedélyezhető (II.a, C-szintü evidencia).

5. A koronáriaartéria-disszekció elsősorban plakkruptúra mellett alakul ki, amelynek megelőzési protokollja az előzőekben, a koronáriabetegségeket tárgyaló fejezetben került ismertetésre. Amennyiben az adott egyénnek viszont volt már koronáriadisszekciója, akkor a versenysport nem, de hobbisport engedélyezhető (ajánlás: III., C-szintü evidencia).

6. Myocardium-brigde-re gyakran derül fény koronária-képalkotó vizsgálatok mellékleleteként. Az eddigi vizsgálatok azt mutatják, hogy amennyiben a myocardium-bridge mellett nincs provokálható iszkémia, vagy komplex kamrai tachiaritmia és az adott egyénnek nincs más szívbetegsége (pl. hipertrófiás cardiomyopathiája), akkor panaszmentes egyének esetén a versenysport engedélyezhető (ajánlás: II.a, C-szintű evidencia).

7. Provokálható iszkémia, vagy típusos panaszok esetén a béta-blokkoló, annak hatástalansága mellett pedig a sebészi ellátás jöhet szóba (perkután intervenció nem) és a versenysport nem, a hobbisport viszont megfelelő egészségügyi kontroll és tanácsok mellett engedélyezhető (ajánlás: II.a, C-szintű evidencia).

\section{Akut szívinfarktust ko̊vetố terhelhetôség}

A heveny szívinfarktust követő rehabilitáció komplex fizikai, szociális és pszichés beavatkozást jelent a beteg életébe és főként az etiológiai tényezőként háttérben lévő rizikófaktorok megfelelő kontrollját célozza meg. A testmozgásalapú kardiális rehabilitációra több kórkép esetében is erős evidenciáink vannak, ezek a szívinfarktus, a stabil angina pectoris és a koronáriarevaszkularizációt követő rehabilitáció (8). Testmozgásalapú rehabilitáció azonban szívtranszplantációt követően, billentyűműtétet követően és krónikus szívelégtelenségben szenvedő betegek esetében is javasolt. A rendszeres fizikai tréning rehabilitációba építése egyaránt csökkenti a teljes halálozást és a kardiovaszkuláris halálozást. Akut szívinfarktust követően a testmozgásalapú rehabilitáció egyaránt csökkenti a fatális- és a nem-fatális kimenetelü ismételt infarktus rizikóját.

Szívinfarktust követően a korai rehabilitációs mozgásprogram elsősorban aerob állóképességi tréninget tartalmaz. Az aerob állóképességi tréning több izomcsoport együttes munkája során valósul meg és elsősorban a pulzus korai emelkedését okozza, a vérnyomásemelő hatása csak mérsékeltebb (szemben a rezisztenciatréninggel) (2. ábra). A rehabilitációs programot megelözően terheléses EKG-vizsgálat szükséges a reziduális iszkémia és az esetleges malignus aritmiák kizárására. A rehabilitációs edzésprogram során monitorozásra kerül a pulzusszám, a Borg-skála segítségével a szubjektív kifáradás mértéke, valamint lehetőség a vérnyomás (9). Az Európai Kardiovaszkuláris Prevenciós és Rehabilitációs Társaság (European Association of Cardiovascular Prevention and Rehabilitation, EACPR) ajánlása alapján terheléses EKG-t a rehabilitációs program elején, valamint új tünet megjelenése esetén javasolt elvégezni.

Aerob állóképességi edzés (8) során a maximális pulzusszám (vagy a maximális oxigénfelvétel, $\mathrm{VO}_{2}$ maximum) 50-80\%-át szükséges elérni az edzések alkalmával (ez az anaerob átmenet közeli pulzuszónát jelenti). $\mathrm{Az}$ edzésekre minimum heti 3 alkalommal (lehetőség szerint minden nap) kerüljön sor és egy edzés minimum 20-30 percig tartson. Az európai ajánlás az infarktust követő edzésprogramot 2-16 hét időtartamban javasolja. A terhelések tünetlimitáltak, vagyis típusos iszkémiás tünet megjelenése esetén a terhelés megszakítandó (6, $7,8)$. Az edzések felügyelete a tünetek, valamint a pulzus- és a vérnyomás mérésével történik. Az iszkémiára utaló EKG-jelek az edzésprogram megkezdésekor és esetleges új tünet megjelenése esetén elvégzett terheléses EKG-teszt segítségével észlelhetők. Mivel az európai ajánlás maximum 16 hetes rehabilitációs időtartama jóval túlmutat a jelenlegi kórházon belüli kardiológiai rehabilitációs hazai gyakorlaton (19 nap), ezért a betegek számára a program otthon, vagy ideális esetben, ambuláns formában is folytatandó. A fizikai tréning természetesen a rehabilitáció befejezését követően is folytatandó, mivel annak hatékony szerepe a kardiovaszkuláris prevencióban egyértelmüen igazolt. A rezisztenciatréning, adott izomcsoportok megerősítését célozza és az aerob edzésmunkával együtt része a legtöbb rehabilitációs programnak. Az izomcsoportok erősítése révén gyor- 
sabban visszanyerhető az ágynyugalom és aktív kórházi kezelés során inaktívvá vált izmok ereje. A rezisztenciaedzést, annak megkezdése előtt ismétlődő rezisztenciaterheléses tesztnek kell megelőznie, amelynek során a kezelőorvos meggyőződik arról, hogy a tréning nem okoz kóros izomsérüléseket, vagy extrém vérnyomás-emelkedést. $A$ rezisztenciaedzést az izmok maximális erejének 30-80\%-án kell, javasolt végezni, aminek meghatározása izomerőméréssel történik.

\section{Nyilatkozat}

A szerző kijelenti, hogy az összefoglaló közlemény megírásával kapcsolatban nem áll fenn velük szemben pénzügyi vagy egyéb lényeges összeütközés, összeférhetetlenségi ok, amely befolyásolhatja a közleményben bemutatott eredményeket, az abból levont következtetéseket vagy azok értelmezését.

\section{Irodalom}

1. Levine BD, Baggish AL, Kovacs RJ, et al. Eligibility and Disqualification Recommendations for Competitive Athletes With Cardiovascular Abnormalities: Task Force 1: Classification of Sports: Dynamic, Static, and Impact: A Scientific Statement From the American Heart Association and American College of Cardiology. J Am Coll Cardiol 2015 Dec 1; 66(21): 2350-2355.

https://doi.org/10.1016/j.jacc.2015.09.043

2. Tulppo MP, Kiviniemi AM, Lahtinen M, et al. Physical Activity and the Risk for Sudden Cardiac Death in Patients With Coronary Artery Disease. J Am Coll Cardiol 2015 Dec 1; 66(21): 2350-2355.

https://doi.org/10.1161/CIRCEP.119.007908.

3. Fritsch $P$, Dalla Pozza R, Ehringer-Schetitska D, et al. Cardiovas- cular pre-participation screening in young athletes: Recommendations of the Association of European Pediatric Cardiology. Cardiology in the Youth 2017; 27: 1655-1660.

https://doi.org/10.1017/S1047951117001305

4. Bohm PH, Scharhag J, Meyer T. Data from nationwide registry on sport-related sudden cardiac deaths in Germany. Eur J Prev Cardiol 2016; 23(6): 649-656.

5. Drezner JA, Sharma S, Baggish A, et al. International criteria for electrocardiographic interpretation in athletes: Consensus statement. Br J Sport Med 2017; 51(9): 704-731.

https://doi.org/10.1177/2047487315594087

6. Börjesson M, Dellborg M, Niebauer J, et al. Recommendations for participation in leisure time or competitive sport sin athletes-patients with coronary artery disease: a position statement from the Sport Cardiology Section of the European Association of Preventive Cardiology (EACP). European Heart Journal 2019; 40: 13-18. https://doi.org/10.1093/eurheartj/ehy408

7. Pellicia A, Sharma S, Gati S, et al. 2020 ESC Guidelines on sports cardiology and exercise in patients with cardiovascular disease: The Task Force on sports cardiology and exercise in patients with cardiovascular disease of the European Society of Cardiology (ESC). European Heart Journal, ehaa605,

https://doi.org/10.1093/eurheartj/ehaa605. Online ahead of print.

8. Piepoli MF, Corra U, Benzer W, et al. Secondary prevention through cardiac rehabilitation: Physical activity counselling and exercise training: Key components of the position paper from the Cardiac Rehabilitation Section of the European Association of Cardiovascular Prevention and Rehabilitation. European Heart Journal 2010; 31(Suppl): 19671974. https://doi.org/10.1093/eurheartj/ehq236. Epub 2010 Jul 19

9. Price KJ, Gordon BA, Bird SR, et al. A review of guidelines for cardiac rehabilitation exercise programmes: Is there an international consensus? Eur J Prev Cardiol 2016; 23(16): 1715-1733.

https://doi.org/10.1093/eurheartj/ehq236. Epub 2010 Jul 1

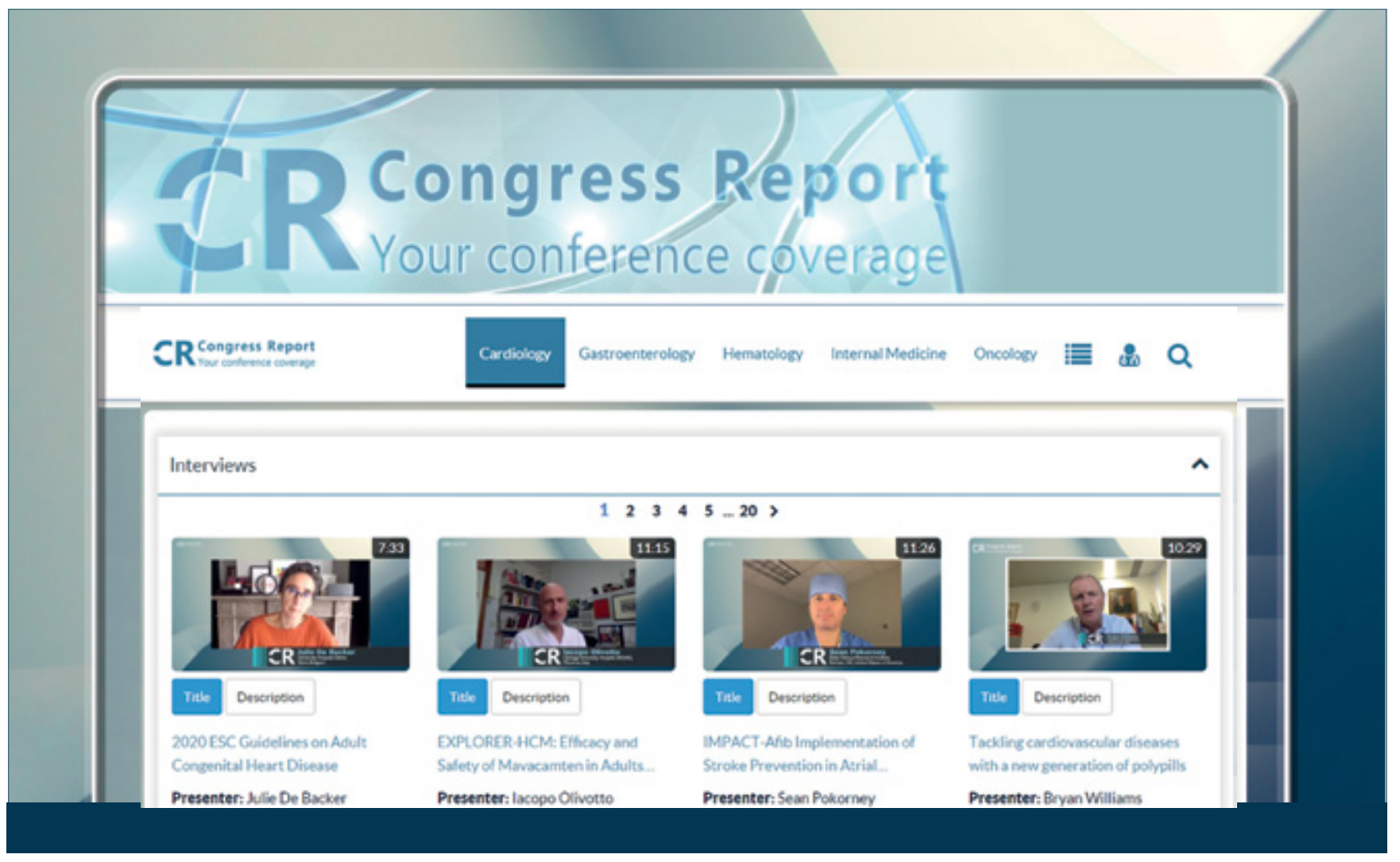

